\title{
Improving Accident Statistics and Expanding the Role of Traffic Psychologists in Brazil
}

\author{
Paulus A J M de Wit \\ Universidade Federal de Santa Catarina, SC, Brasil. \\ Caroline Zaneripe de Souza \\ Psicóloga. \\ Roberto Moraes Cruz \\ Universidade Federal de Santa Catarina, SC, Brasil.
}

\begin{abstract}
Due to the mandatory assessment of psychological fitness to drive of prospective drivers, Brazil has a relatively large amount of traffic psychologists. Since, in general, assessment only happens upon first licensing, the task of these psychologists is fairly limited (as is the scope of the assessment itself). Intention and method: this study aims to perform a critical analysis of possibilities to expand the role of psychologists working in the traffic system in Brazil. A systematic review study of databases and international documents was conducted and a scope of activity of psychologists in this area was built. First result: statistical data is scattered over many agencies. First conclusion: in order to better identify specific tendencies and risk groups in Brazil, statistical data related to accident involvement needs to be better, perhaps centrally, coordinated and consolidated. Second result: international research related to three subgroups of drivers that constitute a significantly increased safety risk can inform future directions for traffic psychology in Brazil. Psychological processes that may underlie these risk increases are discussed. Second conclusion: two subgroups (young drivers and aggressive drivers) could benefit from more than assessment, they could benefit from specific psychological interventions. The third subgroup (elderly drivers) is expected to increase significantly in the future, which asks for clearer policies, with a significant input form psychologists and psychological research. Keywords: Traffic Psychology, Traffic Accidents, Psychological Assessment, Young Drivers, Elderly Drivers, Aggressive Drivers.
\end{abstract}




\section{Melhorando as Estatísticas de Acidentes e Ampliando o Papel dos Psicólogos do Trânsito no Brasil}

Resumo: A avaliação psicológica no Brasil é obrigatória no processo de obtenção da Carteira Nacional de Habilitação $(\mathrm{CNH})$, o que faz com que o país tenha uma quantidade relativamente grande de psicólogos atuando neste segmento. Uma vez que, em geral, a avaliação ocorre somente no momento da obtenção da CNH, a atuação desses psicólogos é limitada (assim como o escopo da avaliação em si). Justificativa e método: este estudo tem por objetivo realizar uma análise crítica das possibilidades de expansão do trabalho dos psicólogos que atuam no sistema trânsito no Brasil. Foi realizado um estudo de revisão sistemática em bases de dados e documentos internacionais, e levantado o escopo de atividades dos psicólogos que atuam nessa área. Primeiro resultado: dados estatísticos estão dispersos em diferentes agências. Primeira conclusão: a fim de entender melhor tendências específicas e grupos de risco, os dados estatísticos relacionados ao envolvimento em acidentes precisam ser melhor coordenados e consolidados. Segundo resultado: pesquisas internacionais relacionadas a três subgrupos de motoristas, que constituem um aumento significativo de risco, podemindicar direções futuras para a psicologia do trânsito no Brasil. Processos psicológicos que possivelmente constituem a base desse aumento de risco são discutidos. Segunda conclusão: dois subgrupos (motoristas jovens e motoristas agressivos) poderiam se beneficiar com algo além de uma avaliação, com intervenções psicológicas específicas. É esperado que o terceiro subgrupo (motoristas idosos) aumente significativamente no futuro, o que demanda políticas mais claras, com contribuições significativas de psicólogos e de pesquisas em psicologia do trânsito.

Palavras-chave: Psicologia do Trânsito, Acidentes de Trânsito, Avaliação Psicológica, Motoristas Jovens, Motoristas Idosos, Motoristas Agressivos.

\section{Mejorando las Estadísticas de Accidentalidad y Ampliando el Papel de los Psicólogos del Tráfico en Brasil}

Resumen: La evaluación psicológica en Brasil es obligatoria en el proceso de obtención de la licencia de conducir; así, el país tiene una gran cantidad de psicólogos del tráfico. Una vez que generalmente la evaluación ocurre solamente en la obtención de la licencia, la tarea de estos psicólogos (y también el alcance de la evaluación) es muy limitada. Justificación y método: este estudio tiene como objetivo presentar un análisis crítico de las posibilidades de expansión del trabajo de psicólogos que actúan en el sistema de tráfico en Brasil. Se llevó a cabo un estudio en base de datos y documentos internacionales y se levantó el ámbito de actividad de los psicólogos. Primer resultado: datos estadísticos están dispersos en diferentes agencias. Primera conclusión: para comprender mejor las tendencias específicas y subgrupos de riesgo, los datos estadísticos de accidentes de tránsito necesitan sermejorcoordenadosy consolidados. Segundoresultado: investigacionesinternacionales relacionadas a tres subgrupos de conductores, los cuales constituyen un aumento significativo de riesgo, pueden indicar direcciones futuras para la psicología del tránsito en Brasil. Se discuten procesos psicológicos que posiblemente forman la base de este riesgo. Segunda conclusión: dos subgrupos (conductores jóvenes y conductores agresivos) podrían tener beneficios con algo más que una evaluación, incluyendo intervenciones psicológicas específicas. Es esperado que el tercer subgrupo (conductores ancianos) aumente significativamente en el futuro, lo que demanda políticas más claras, con contribuciones significativas de psicólogos e investigaciones psicológicas. Palabras clave: Psicología del Tráfico, Accidente de Tráfico, Evaluación Psicológica, Conductores Jóvenes, Conductores Ancianos, Conductores Agresivos. 


\section{Introduction}

In Brazil a psychological assessment is compulsory for everyone who applies for a driver's license. The government recommends assessment of the following areas: perception, information processing, decision-making, behavior (including self-report) and personality traits; and also allows the following assessment-instruments and techniques: individual interviews, psychological tests (agreed upon by the Federal Council of Psychology), group-dynamics and "listening and verbal interventions" (Brasil, 2012, p. 3). The assessments are outsourced to qualified third-party traffic psychologists. These psychologists have a great margin of freedom in selecting the areas they assess and the type of assessment instruments they use. No traffic psychologist assesses all areas or applies the full range of assessments.

Many of them only apply one type of assessment - most commonly an intelligence test. Furthermore, in the majority of cases, the psychological assessment only happens upon the first application, as in most cases there is no requirement for a reassessment upon renewal of the license ${ }^{1}$. Therefore, although the idea to require psychological assessment of all drivers may be sound, the practical execution is limited and rather random. The assessment offers no more than a momentary snapshot of a particular part of the psychological state of the aspiring driver. The assessing psychologist bases his/her decision on whether the applicant is psychologically fit to drive on this snapshot.

The Global Status Report on Road Safety 2015, published by the World Health Organization (WHO), shows a steep rise in the amount of traffic-related deaths in Brazil (WHO, 2015). Table shows fatal traffic victim data comparing Brazil to the United States, Japan, France and the United Kingdom (Brazilian data from 2004; all others from 2005). This data provides another perspective on the seriousness of the problem.

Although Brazil is likely to have a much larger ratio of traffic psychologists per inhabitant than the other countries shown in Table (because of its mandatory psychological assessment of (prospective) drivers), their input is clearly not enough. Improving the overall standard of driving and fitness for driving of Brazilian drivers should not only significantly reduce traffic-related accidents; it should also significantly reduce the overall death and injury rate, as well as the overall costs related to traffic accidents. Traffic psychologists are by no means the only ones responsible for the assessment and maintenance of fitness for driving; nevertheless, improving the psychological assessment and expanding the role of traffic psychologists could make a significant difference.

\section{Method}

This article considers international data and research related to accident risk of drivers with the goal of identifying areas in which the role of traffic psychologists in Brazil can be expanded. In particular it considers data and research pertaining to sub-groups of the driver population with increased accident risk and attempts to compare this to available data concerning the Brazilian driver population.

Table

Fatal victims per 100,000 inhabitants and per 100,000 vehicles in Brazil, the USA, Japan, France and the UK.

\begin{tabular}{lcccccc}
\hline Country & Year & $\begin{array}{c}\text { Population } \\
\text { (millions) }\end{array}$ & $\begin{array}{c}\text { Total fleet } \\
\text { (millions) }\end{array}$ & Fatal victims & $\begin{array}{c}\text { Fatal victims per } \\
100,000 \text { inhabitants }\end{array}$ & $\begin{array}{c}\text { Fatal victims per } \\
100,000 \text { vehicles }\end{array}$ \\
\hline Brazil & 2004 & 182 & 39 & 43,000 & 24 & 110 \\
USA & 2005 & 296 & 245 & 43,400 & 15 & 18 \\
Japan & 2005 & 127 & 83 & 17,900 & 14 & 22 \\
France & 2005 & 61 & 37 & 5,300 & 9 & 14 \\
UK & 2005 & 58 & 33 & 3,200 & 6 & 10 \\
\hline
\end{tabular}

Adapted from: Por vias seguras (2007).

\footnotetext{
${ }^{1}$ There are two exceptions to this: drivers who declare that they are professional drivers need to do the psychological assessment upon renewal of their license (every five years) (Lei $n^{\circ} 10.350,2001$ ) and medical doctors can require patients to undergo a psychological assessment to verify their psychological fitness to drive (Brasil, 2001).
} 
We briefly review: (bio)-psychological theories that seek to explain increased risk in these sub-groups; international research and policies to reduce this risk; and what this can mean for the further development of traffic psychology in Brazil. Research concerning accident risk is informed by accident statistics; we will therefore first look at the way such data are being used in international research and at the availability of relevant statistical data in Brazil.

\section{Results and Discussion I}

\section{Statistics relating driver subgroups to accident involvement}

Examples of data relating specific age groups to accident involvement

Many international statistics relating the age of drivers to their involvement in accidents show that young drivers (roughly 16-24yrs) and elderly drivers $(70+/ 75+y r s)$ appear to have a significantly higher risk of being involved in accidents. For example, Mori and Mizohata (1994) and Williams (2002) extensively analyzed the data related to fatal accidents for Japan and the US respectively and report a significant increase in road death and fatal accident involvement in both age groups. However, a closer look at crash statistics reveals that these figures may not be as straightforward as they appear at first sight. An increased risk for younger drivers seems most robust and features in almost all international reports and articles. Several researchers however debate the increased risk for elderly drivers. Distributions such as those mentioned in Mori and Mizohata's and Williams' articles depend on specific manipulations of the raw data. For example, correlating fatal crash involvement with gender, age group per million miles travelled (as in Williams, 2002) considerably increases the relative crash involvement of both young and elderly drivers, but this does not mean that young and elderly drivers are involved in more crashes than middle-aged drivers. Quite the contrary is true. The majority of (fatal) crashes involve middle-aged drivers. Worldwide there are far less young drivers and elderly drivers than there are middle-aged drivers. Furthermore, in general those young and elderly drivers drive significantly less than middle-aged drivers. Thus, although the accident risk for young and (arguably - see below) for elderly drivers is in itself (often considerably) higher than for middle-aged drivers, middle-aged drivers are involved in the majority of crashes. There are many more middle-aged drivers than young and elderly drivers; the age-band designating "middle-age" is much wider than those designating "young" and "elderly"; and middle-aged drivers drive significantly more than young and elderly drivers. The specific manipulations used to demonstrate the relatively high accident involvement of young and elderly drivers skews the data in a manner that renders the absolute accident involvement of middle-aged drivers invisible.

Langford, Methorst and Hakamies-Blomqvist (2006) argue that the conclusion of many researchers that elderly drivers have an increased risk of crash involvement is likely mistaken because it may be based on so-called "low mileage bias". Their research shows that drivers of all age groups have an increased accident-risk when they drive less, irrespective of their age group. Since elderly drivers in general drive less than middle-aged drivers, their relative overrepresentation in traffic accidents can be explained solely by their reduced mileage, and it is not necessary to assume other causes (such as deterioration of drive-related abilities due to age).

Several distributions displayed in the Mori and Misohata article (1994) show all traffic deaths per age group, not only driver involvement in fatal accidents as, for example, in Williams' article. Here additional factors can explain the high fatality in the elderly, particularly the increased frailty of the elderly. Due to their increased frailty, elderly people involved in accidents are more likely to die as a result of sustained injuries than younger accident-victims.

Figure 1 gives an example of more recent (2008) data pertaining to the overall driver involvement in fatal crashes per age-group (and per sex) in the US per 100,000 population. It shows no over-involvement of elderly drivers, but a clear peak in the involvement of male drivers in the age-group 21-24 years.

The UK-based RAC Foundation ${ }^{2}$ publishes data concerning road safety in relation to young and elderly

${ }^{2}$ The RAC Foundation is a charity that came forth out of one of the two national motorist clubs in the UK, the Royal Automobile Club (RAC). It "is a transport policy and research organization, which explores the economic, mobility, safety and environmental issues relating to roads and their users". (RAC Foundation, 2016). 
drivers on its website. The information is based on its own research (as indicated on the site). According to the website, while 17-24 year-old drivers made up approximately 7 percent of all full driving license holders in the UK in 2013, they accounted for 18 percent of all drivers involved in reported road accidents. About elderly drivers, the website states that:

(...) Comparisons of collision rates in several countries indicate that, when all severity collision rates are compared on a per-licensed-driver basis, older drivers up to the age of 80 have collision rates that are comparable to those of middle-aged drivers. The comparatively greater fatality rates of older drivers can be accounted for by their greater frailty and lower resilience to injury (http://www.racfoundation.org/motoring-faqs/safety).

Statistical manipulations as those implied in the data presented by the RAC Foundation and others qualify the available data and are important to determine the relative level of driver involvement in crashes per age group as well as specific risk factors that play a role. However, as this very brief review indicates, it is important to realize how exactly the raw data has been manipulated to support specific conclusions. Several interpretations based on specific statistical manipulations may not be valid when put to the test. Greater transparency on the relation between the raw data and specific statistical manipulation is needed.

Furthermore, often the data is country specific and findings should not be generalized between countries (or even between different states). An interesting example of this phenomenon can be found in a report published by the European Commission concerning fatal accidents and the involvement of young drivers. The online report (entitled Characteristics of these crashes) contains the following diagram comparing certain characteristics of fatal accidents between three different countries:

Apart from the overrepresentation of young drivers in fatal accidents in all three countries, the data presented in Figure 2 show that in these three countries the distribution of accident types is actually quite similar for both young drivers and their middle-aged counterparts and it clearly shows that these distributions are to a certain extent country specific ${ }^{3}$. More recent insurance-related data from the US reveal statistics that indicate a significantly increased risk for male drivers, particularly in the age groups 18-29 and $65+$ (see Figure 3 ). Such data are not readily replicated in many other countries; however, recent Brazilian data also show a great discrepancy between male and female drivers with regard to involvement in fatal crashes. (Note that the increased fatality of elderly drivers is replicated in elderly passengers and may therefore indeed indicate increased frailty.)

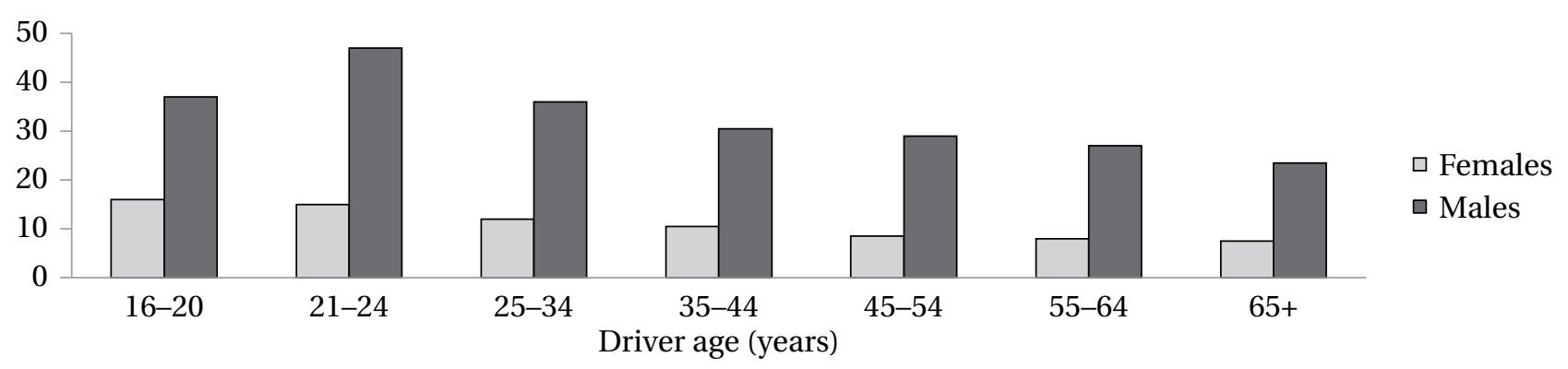

Adapted from: NHTSA's National Center for Statistics and Analysis (2008).

Figure 1

Driver involvement rates in fatal crashes by age and gender per 100,000 population, US, 2008.

\footnotetext{
${ }^{3}$ The choice to present separate data for single car accidents, alcohol involvement, the presence of passengers and accidents happening in weekend nights appears to reflect other research findings, which show that young drivers are particularly overrepresented in accidents involving these factors. Such findings are one of the reasons why in some countries the introduction of graduated driver licensing has sought to limit young drivers' exposure to these factors by not allowing them to drive at night and with teenage passengers and by imposing very strict laws on alcohol consumption for under-21-year-olds. The UK and other European countries are contemplating similar measures. The data presented in figure 2 indicates however that the distribution of specific characteristics of fatal accidents is country-specific and, that - apart from such measures - additional, country-specific approaches may be called for.
} 
Examples of data relating aggressive driving to accident involvement

What do statistical data tell us about the accident-involvement of drivers that engage in aggressive driving behaviors? In 2012 the New Zealand Ministry of Transport released the report High-risk drivers in fatal and serious crashes: 2006-2010. The report uses a defi- nition of high-risk drivers that does not cover the full range of behaviors listed elsewhere as aggressive driving (see the second part of this article) and is probably quite country-specific; nevertheless, the report illustrates the way in which certain categories of aggressive driving behavior feature in overall accident statistics and can serve as a model of detailed accident statistics.

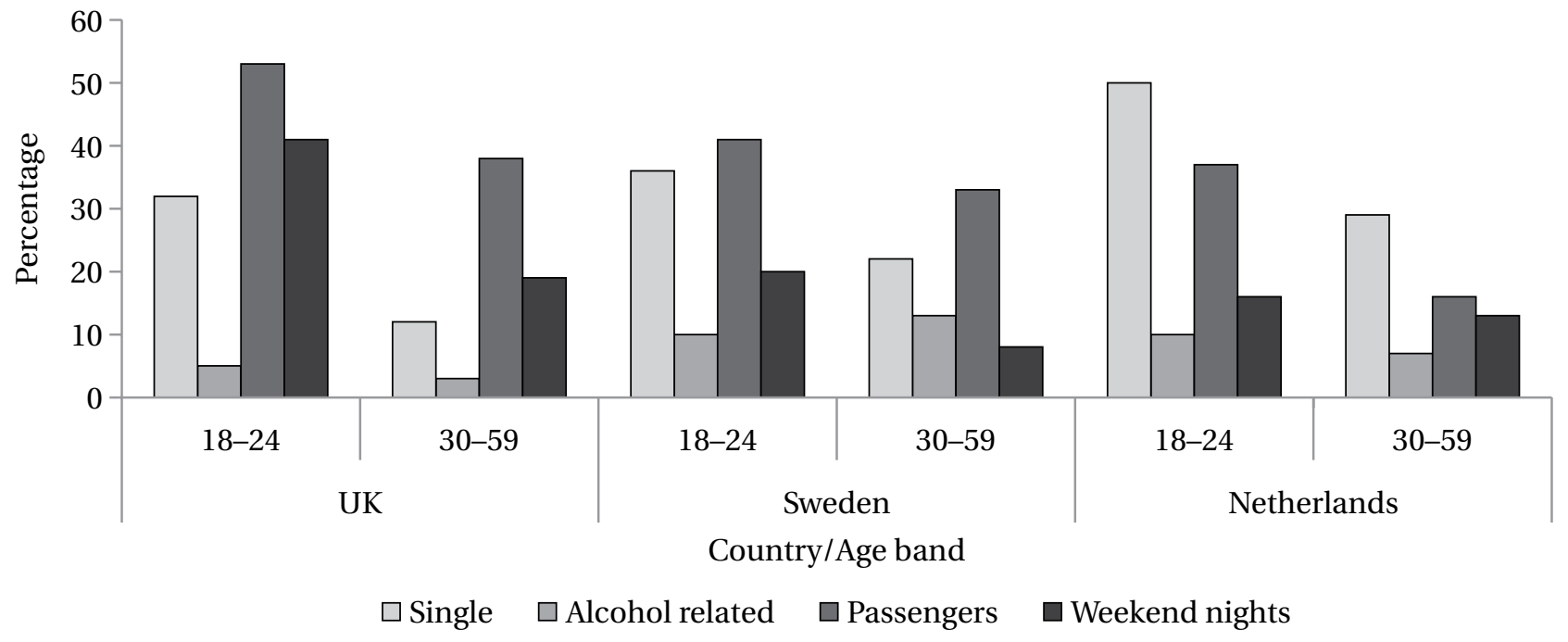

Adapted from: European Road Safety Observatory (2007).

Figure 2

Percentage of fatal crashes that are single car crashes, alcohol related crashes, crashes with passengers injured or killed, and weekend night crashes in the age bands 18-24 and 30-59 for the UK, Sweden and the Netherlands.

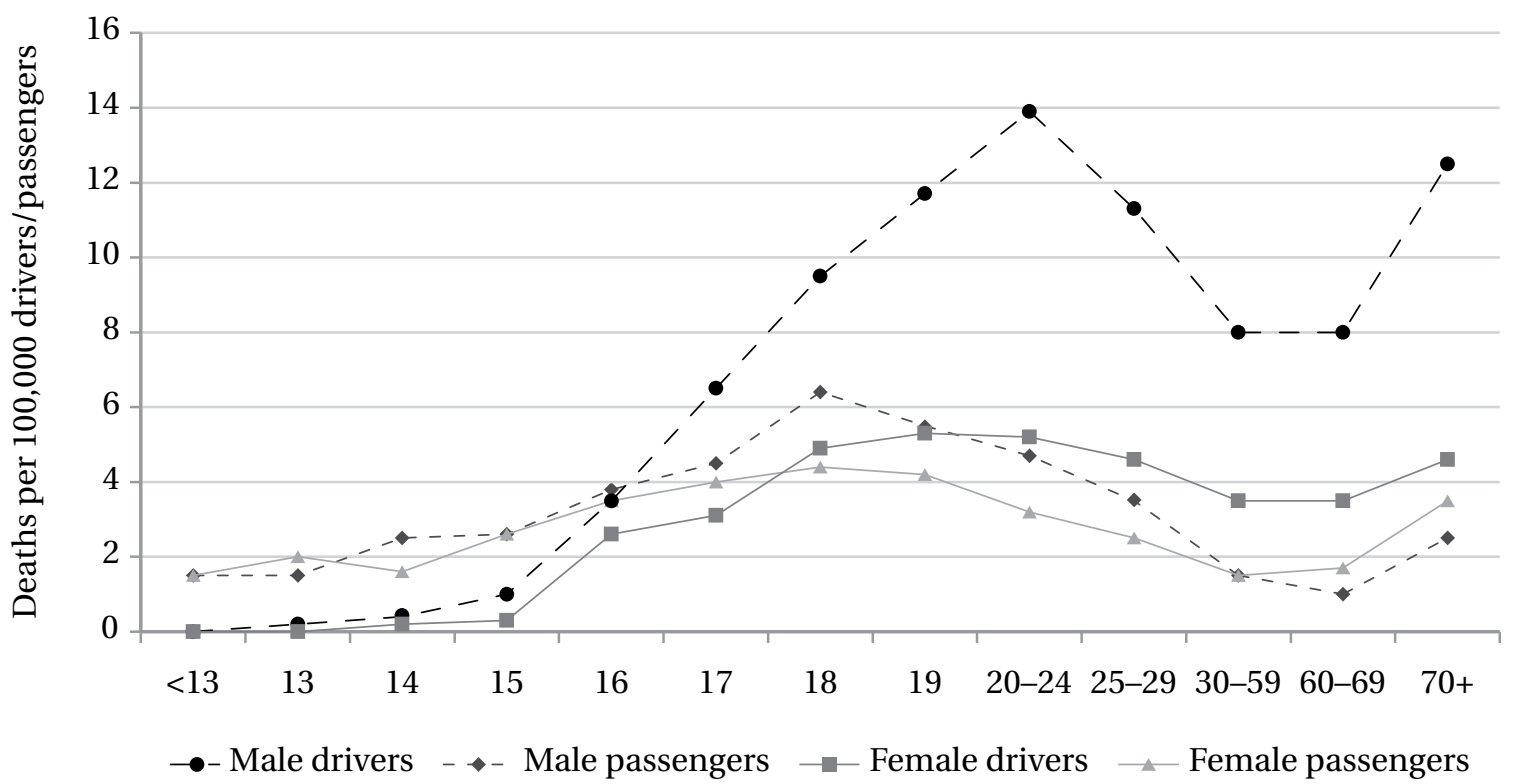

Adapted from: Insurance Institute for Highway Safety; Highway Loss Data Institute (2015).

Figure 3

Death rates in passenger vehicles per 100,000 people by seating position, age and gender in the US in 2013. 
The report defines high-risk drivers as: unlicensed and disqualified drivers (including drivers who are forbidden to drive or who have an expired license or the wrong license class for the vehicle being driven); drivers identified as evading enforcement or racing or showing off at the time of the crash; drivers with a blood alcohol level of at least fifty percent over the adult legal limit (i.e. $120 \mathrm{mg} / 100 \mathrm{ml}$ ); repeat alcohol offenders, specifically drivers in alcohol-related crashes who have at least one prior alcohol conviction in the previous 5 years; repeat speed offenders, specifically drivers in speed-related crashes who have at least two prior speeding offences in the previous 5 years, with at least one involving a speed that exceeded the speed limit by $21-30 \mathrm{~km} / \mathrm{h}$.

The report states that between 2006 and 2010 in $34 \%$ of fatal crashes and in $22 \%$ of crashes with serious injury high-risk drivers were at-fault, meaning: they had primary responsibility for the crash (based on standardized crash analysis, not on legal liability). Of the ample statistics presented in the report we present one example. Figure 4 compares high-risk at fault drivers with other at-fault drivers in fatal crashes, per age group.

\section{Brazilian data}

The international data shown in the previous subsections pertain to specific examples. These examples illustrate certain tendencies, but they also show that to become better understandable, the available (raw) data need refined statistical manipulation as well as further analysis. Furthermore these examples show that, to a certain extent, the data appear to be country-specific, which means that one should be careful in generalizing specific tendencies across countries. Since Brazil is a big country in which the traffic culture greatly varies between different states and regions, accident risk characteristics are likely to be state- and region-specific.

Attempts by our team to obtain relevant data in Brazil that relates accident risk to age groups and other subgroups has revealed that such statistics are not readily available or accessible. The statistics that are accessible are too general and, although overall there may be enough data available to conduct the more refined statistical analysis necessary to determine the relative risk pertaining to specific age-groups and other subgroups, such data are scattered over many different federal and state agencies, and collecting, consolidating and analyzing the necessary data will be a massive undertaking.

We will present an example of statistical data available in Brazil and indicate what is necessary to make the data relevant in order to determine an overrepresentation of drivers of specific age-groups or other subgroups in traffic accidents.

On its website Por Vias Seguras publishes many statistics pertaining to accident risk (not only traffic

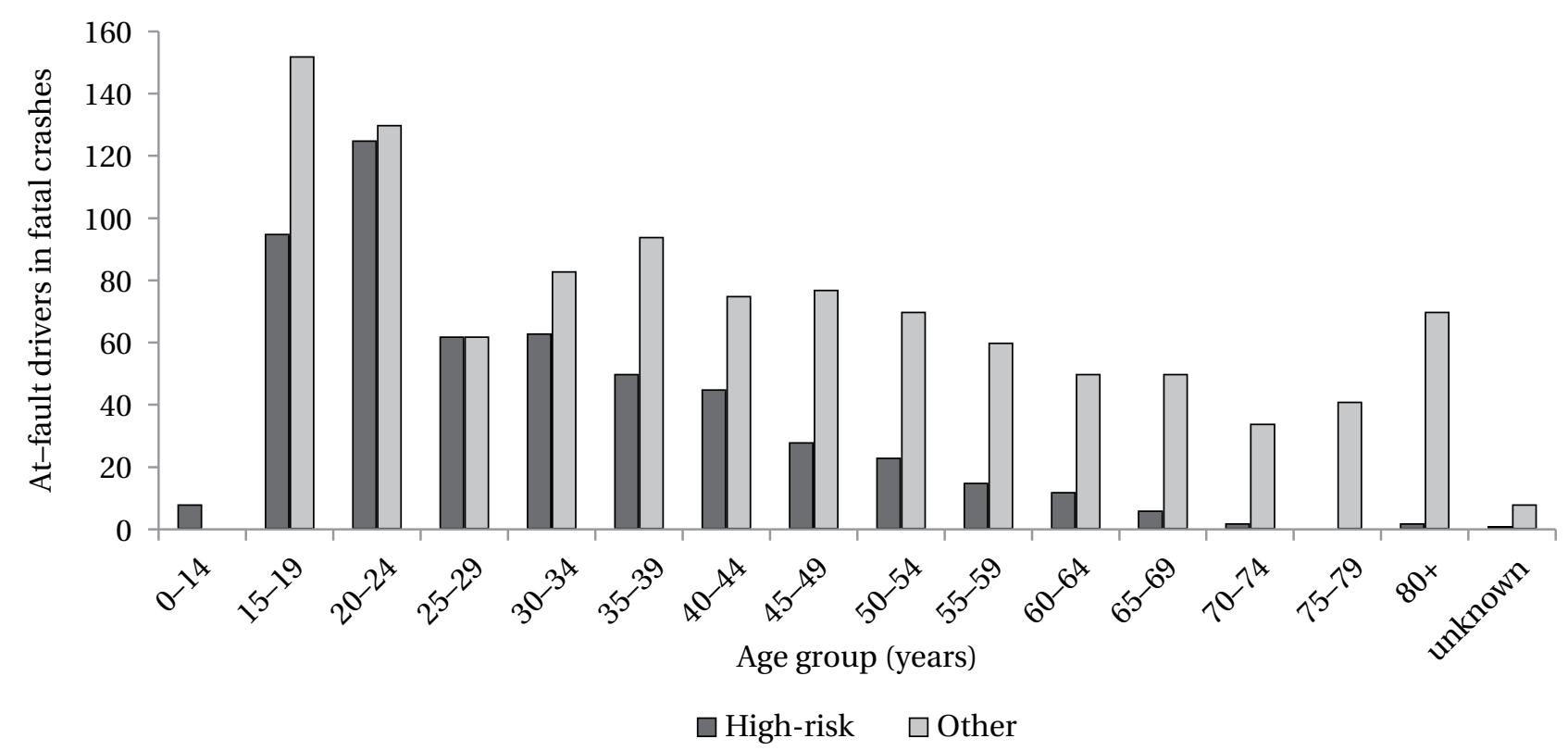

Adapted from: Ministry of Transport (New Zealand) (2012).

Figure 4

At-fault drivers in fatal crashes in New Zealand (2006-2010) divided by high-risk and other and by age group. 
related). Data are presented in many different ways, for example in the form of diagrams such as the one shown in Figure 5. It is clear form many data available on the website that the amount of deaths resulting from traffic accidents peaks in late adolescence and early adulthood, which appears to coincide with international data about young drivers. However, the data do not only pertain to drivers, but to all traffic deaths.

In Figure 5 the data has been adjusted to the ratio of the different age groups in relation to the total population. Therefore figure 5 shows the risk of involvement in a fatal traffic accident related to age. Figure 5 shows that the age in which the increase in risk of a fatal traffic accident coincides with the minimum age for obtaining a driving license and it is also possible to see a rise in risk in the 70+ age-groups. However, to be able to come to more adequate conclusions, data relating driver's age to accident risk and adjusting this data to the ratio of young and elderly drivers in relation to the total population of drivers is necessary. As briefly discussed in the first subsection, since the risk in this calculation is based on actual traffic deaths, the rise in risk for higher age groups may have to be attributed to increased frailty, not necessarily to increased accident involvement. Further research is necessary to better qualify data.

The Departamento Nacional de Infraestrutura de Transportes (DNIT, regularly updated, used statistics from 2015) publishes very detailed annual statistics (based on data from the Departamento de Polícia
Rodoviária Federal), relating driver age group to involvement in accidents, both per state and federally. But, again, in order to be able to determine the relative risk per age-group one would also need data that show the ratio of drivers per age-group in relation to the total driver population. For an even more detailed analysis, more specific data is needed relating accidents to: type of accident (intersection; right of way; speed-related - all per gender and per age-group), alcohol-consumption (per gender and per age-group), time of day (per age-group); day of the week (per age-group); presence of passengers and their age (per gender and per age-group); mobile phone use (per gender and per age-group). At present, state-specific data are available up to 2011, this includes the number of deaths and/or injuries (for drivers as well as for passengers), number of victims and number of vehicles involved (single-vehicle or two and more vehicles) - all per gender and age-group of the driver responsible for the accident. Without further information that clarifies the ratio of specific age-groups (per gender) to the total driver population, these data reveal no specific information pertaining to the relative risk of accident-involvement for specific age-groups.

With regards to aggressive driving and in relation to the statistics from New Zealand shown in the previous subsection: we have no access to comparable data in Brazil. Although the data presented was specific for New Zealand ${ }^{4}$, they demonstrate the type of data traffic psychologists would need, to be able to identify

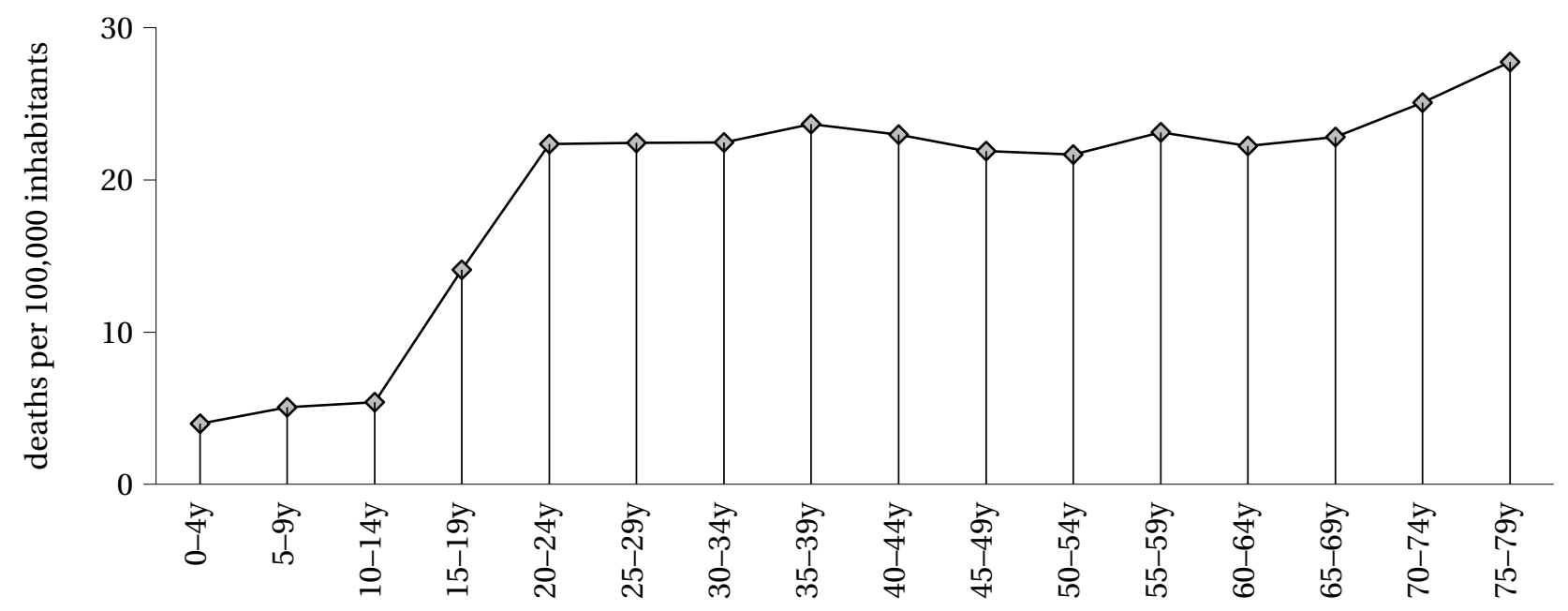

Adapted from: Por Vias Seguras (2007).

Figure 5

Risk of fatal traffic accident related to age in 2000.

\footnotetext{
${ }^{4}$ In particular the prevalence of unlicensed driving probably does not translate into many other countries - at least there is little or no reference to it in other publications. Additionally - as was discussed earlier in relation to Figure 2 - the particular distribution of speeding, substance abuse etc. is likely to be specific for New Zealand.
} 
and determine the occurrence and magnitude of specific aggressive driving behaviors and to understand the risk they pose for traffic safety in Brazil. Such knowledge in turn could inform assessment and intervention procedures. On the basis of our present knowledge we predict that aggressive driving behavior is a major contributor to traffic risk in Brazil and that its distribution over the different age groups is quite different from the distribution found in New Zealand, with a much greater involvement of middle-aged drivers. But to be certain, we need proper data.

\section{Conclusion I}

\section{Recommendations concerning statistical data}

International statistical data show certain tendencies relating driver's age (and gender) to risk of involvement in a traffic accident. In some countries analysis of the available data is accurate enough to inform policies aimed at reducing accident involvement of the specific age groups. In Brazil the amount of data collected annually is high, but these data are scattered over many federal and state agencies. To be able to effectively use these data, an overall coordination and consolidation of the data is needed. It would be advisable to appoint a specific body to be in charge of this coordination. As well as a consolidation of the available data, clear advice related to their collection as well as coordination of the type of data to be collected are needed. Furthermore, specific analyses need to be developed to appropriately process the collected data. Only then the available data will accurately inform policies and measures aimed at reducing the risk of accident involvement and, ultimately, at the reduction of traffic-related deaths and injuries. And only then the data will accurately inform assessment-choices and (possibly) intervention strategies by traffic psychologists.

\section{Results and Discussion II}

\section{(Bio)-psychological maturity and driving}

As mentioned in the introduction, the present role of traffic psychologists in Brazil is mostly limited to providing a momentary snapshot of a particular aspect of the psychological state of the prospective driver. On this snapshot the psychologist bases his/her decision whether the prospective driver is psychologically fit to drive. One of the goals of this article is to demonstrate that the role and importance of psychological assessments and interventions in Brazil can be greatly expanded in order to improve the overall standard of and fitness for driving, not only of prospective drivers, but also of existing drivers.

As indicated in the previous section, statistical analysis plays an ever-increasing role in the determination of risk of accident-involvement of specific parts of the driver population. International research shows certain tendencies; especially those related to specific age groups and gender-related tendencies. Asindicated above, the consolidation and level of statistical analysis of the available data in Brazil needs to be improved dramatically to be of use to inform policies and measures to reduce accidents. This also goes for the further development of psychological assessments and interventions related to accident risk of drivers. Refined statistical analysis can indicate specific concerns and these can be correlated with the existing understanding of human, biological and cognitive development (Bertelle, Duchamp, \& Kadrri-Dahmani, 2009) as well as with other psychological variables. This section reviews some of the available theoretical support and evidence for specific areas of (bio)-psychological development that can explain the data presented by international statistics related to accident involvement of drivers. Apart from young and elderly drivers, it will also look at theories and evidence relating psychological development and psychological traits to aggressive driving. Aggressive driving significantly increases accident risk, its many definitions include: speeding, running a red light, tailgating, blocking vehicles, improper passing, failing to yield right of way, failing to keep on the right side of the road and driving under influence (of alcohol and other drugs). Galovski and Blanchard (2004) also include: horn honking, flashing high beams and personal attacks on fellow drivers (ranging from gesturing and insults to physical assault). Other forms of risky driving are: not wearing a seatbelt and driving while distracted - especially by the use of mobile devices.

\section{Bio-psychological maturity of young drivers}

Advocates of graduated driver licensing, which seeks to limit the exposure of novice young drivers to high-risk driving situations such as driving at night and driving with teenage passengers, frequently attribute the overrepresentation of young drivers in crash involvement to a general lack of driving experience. 
For example, McKnight and Peck (2003) wrote: "Initial attempts at unsupervised driving by teenage novices are characterized by inordinately high risk. (...) While estimates as to the magnitude of risk may vary, it is clear that introduction to the demands of the traffic environment are fraught with danger" (p. 85).

Although this lack of experience certainly appears to play a role in the overrepresentation of young drivers in crash involvement, many studies - including those referring to increased accident risk of young drivers - emphasize the more general tendency of young people to engage in riskybehavior. Almost thirty years ago, in a review article about adolescent risk-taking behavior (not directly related to driving), Tonkin (1987) wrote:

Adolescents are commonly identified as society's risk takers. (...) Today's adolescent enters puberty earlier and is taller, heavier, and healthier than the adolescent of yesteryear (...). The knowledge base and intellectual skills of adolescents have advanced remarkably in some school systems. However, [through the ages] the behavior of adolescents (...) remains essentially the same. The available evidence supports the assumption that, aside from advances in physical and intellectual status, the adolescent host has changed little in recent decades. (p. 213).

More recently neuroscience has begun to link specific adolescent behaviors to developmental stages in the maturation of the central nervous system. Although neuroscientists warn against assuming any direct causality between brain maturation and behavioral tendencies, there appears to be enough evidence to show a clear correlation. Steinberg (2008) points out that two independent changes take place in the brain between childhood and adulthood. First there are changes in what he calls the brain's "socio-emotional system" leading to increased reward-seeking and risk-taking. Later, the brain's "cognitive control system" changes, which leads to an improved self-regulation and to a decline in risk-taking. Steinberg: "The differing timetables of these changes - the increase in reward-seeking, which occurs early and is relatively abrupt, and the increase in self-regulatory competence, which occurs gradually and is not complete until the mid-20s, makes mid-adolescence a time of heightened vulnerability to risky and reckless behavior" (Steinberg, 2008, p. 82). In his article Steinberg argues that the increased tendency to engage in risky behavior in adolescence is not related to cognitive factors as such, but to social and emotional factors. He writes:

The fact that adolescents are knowledgeable, logical, reality-based, and accurate in the ways in which they think about risky activity - or, at least, as knowledgeable, logical, reality-based, and accurate as their elders - but engage in higher rates of risky behavior than adults raises important considerations for both scientists and practitioners.

(...) I argue that the factors that lead adolescents to engage in risky activity are social and emotional, not cognitive; that the field's emerging understanding of brain development in adolescence suggests that immaturity in these realms may have a strong maturational and perhaps unalterable basis; and that efforts to prevent or minimize adolescent risk-taking should therefore focus on changing the context in which risky activity takes place rather than mainly attempting, as current practice does, to change what adolescents know and the ways they think. (p. 80)

Johnson, Blum and Giedd (2009) distinguish "hot" and "cold" cognition. They define "hot cognition" as referring "to conditions of high emotional arousal or conflict" (p. 218). They point out that most research into risk-taking behavior of adolescents has concerned itself with "cold cognition" ("low arousal, no peers and hypothetical situations"), while risk-taking behavior appears to be ruled by "hot" cognition. Like Steinberg (2008), they relate hot and cold cognition to different areas in the nervous system, which do not develop at the same time. They conclude: "adolescent maturity of judgment and its putative biological determinants are difficult to disentangle from socio-emotional context".

Such findings suggest that a psychological assessment that only focuses on measuring (cold) cognitive functions does not predict potential risk-taking behavior of (prospective) (young) drivers. The general assumption that a certain (minimum) level of cognitive functioning inhibits risk-taking and that education should be able to activate this inhibition appears mistaken. Recent research shows that the cognitive control system mentioned by Steinberg (also known as executive function) gradually matures duringlate adolescence and early adulthood and that its development is only completed 
in the mid-twenties. This cognitive control system is not targeted in regular cognitive assessments used by traffic psychologists. Present psychological assessments may need to be expanded to be able to predict increased tendencies to engage in risk-taking behavior. However, since such tendencies are a general attribute of young people, other measures may be needed to reduce accident risk of young drivers. As Steinberg puts it: "because some forms of risk-taking by adolescents put individuals of other ages at risk (...), public health experts agree that reducing the rate risk-taking by young people would make a substantial improvement in the overall well-being of the population (...)" (Steinberg, 2008, p. 79). Several countries, such as Australia, New Zealand and several states in the USA, have introduced graduated driver licensing, while several countries in Europe are actively investigating such systems. Graduated driver licensing of young drivers does appear to reduce the risk of accident-involvement, but perhaps future developments in psychological evaluation combined with psychological interventions focusing on "hot" cognition might play a role in this reduction too. Obviously this needs further research.

\section{Biological and cognitive tendencies in elderly drivers}

Mori and Mizohata (1994) fill almost an entire page of their article listing international research evidencing the biological and cognitive deterioration that comes with growing older. At the end of this list they conclude rather noncommittally:

The above psychological, physiological, and pathological findings indicate that such functions as eyesight, audition, judgment (attention), and reaction deteriorate with advancing age, (...). Advanced stages of deterioration would mean that many older people would have several handicaps. However, most old people have superior characteristics such as psychological stability and deeper insight backed by ample experience, compared to young or middle-aged people. (p. 392).

Cobb and Coughlin (1998) summarize the areas of concern associated with elderly drivers, stating that "[s]tudies have found four areas of concern: visual search, recognition of a problem, evaluation (making a decision to act) and response (foot to brake pedal).
Each reflects "a general slowing...with advanced age"” (p. 414). Many countries require mandatory assessment of drivers of 75 years and older upon renewal of their license, while the validity of their license is often shortened from the regular ten or five years to three years or shorter. Mandatory assessments are mostly limited to a basic medical assessment and/or to a self-report questionnaire. If the outcome of this preliminary assessment calls for it, more extensive tests follow, including psychological tests. Furthermore, in most countries health professionals and police officers have a duty to notify licensing authorities if they have concerns regarding the fitness to drive of a driver (including an elderly driver). The same is expected of drivers themselves and of their relatives. Langford et al. (2006) - cited earlier in the section about statistics in relation to "low mileage bias" - argue against a mandatory assessment (be it medical or psychological) of elderly drivers on the basis of statistical data alone.

The Driving with Dementia Working Group of three District Health Boards in New Zealand has published very clear clinical guidelines concerning mild cognitive impairment and dementia in relation to driving safety (Fisher, \& Thomson, 2014). Part of the recommended assessment procedure concerning mild cognitive impairment and dementia in relation to driving safety consists of dementia staging, using the Clinical Dementia Rating Scale (Morris, 1993) by means of an existing clinical cognitive assessment (MMSE, MoCA, RUDAS, or ACE-III). When the outcome indicates moderate or severe dementia, the driver must stop driving; when the outcome indicates mild dementia, driving safety is uncertain and further review is necessary; when the outcome indicates mild cognitive impairment, most are considered safe to drive, but restrictions similar to those in graduated driver licensing may be imposed (e.g. only local and no night-time driving). It should be noted that such restrictions are common across many countries; they reduce risk, but nevertheless allow drivers with mild cognitive impairment to maintain a level of mobility.

\section{Psychological maturity, traits and aggressive driving behavior}

In 1940 Ross noted that human factors accounted for $90 \%$ of 58,550 motor vehicle accidents in seven Michigan cities. Mechanical failure and road conditions 
accounted for no more than $10 \%$. His figures are often generalized beyond the seven Michigan cities. Since 1940 vehicle safety has advanced significantly and road conditions have improved likewise; this has led many to assume that at present human factors must account for the vast majority motor vehicle accidents. Looking at those human factors, Stradling and Parker (1997) distinguish between lapses, errors and violations. Of those three only violations imply intent and are related to aggressive driving. Galovski and Blanchard (2004) conducted an extensive review of aggressive driving, and summarize: "Aggressive driving behaviors vary in range and intensity from mild infractions of the law and discourtesies to clear antisocial behaviors and deliberate attempts to harm others" (Galovski, \& Blanchard, 2004, p. 108).

Concerned with the prevalence of aggressive driving, researchers and other implied parties have tried to determine whether aggressive and risky driving behavior can be predicted with the help of diagnostic or psychological assessment tools and also whether interventions that help affected drivers manage their behavior can be developed. Galovski and Blanchard (2004) have done both and report about it in their extensive article about road rage. Under the heading Personality variables of aggressive drivers they catalogue various attempts at assessing and classifying aggressive driving behavior. In the 1950s administration of the Minnesota Multiphasic Personality Inventory and the Rozenzweig Picture Frustration Study on samples of accident- and violation-free drivers and accidentand violation-incurring drivers, showed significant differences between these two groups (Galovski, \& Blanchard 2004, p. 117). More recently (in the early 1990s) neuroticism and psychoticism, as identified by the Eysenck Personality Questionnaire, were found positively correlated with aggression and driver stress (pp. 118-119). Neuroticism has also been associated with relatively ineffective coping skills adding another link to driver stress (p. 119). Finally, when administering the standardized Structural Clinical Interview for DSM-IV Axis I and II disorders on a sample of aggressive drivers, researchers found that these drivers exhibited significantly more Axis I and II pathology than a control group of nonaggressive drivers (p. 120). Such results suggest that it is possible to assess prospective as well as existing drivers for tendencies towards aggressive driving behavior.

Stephens and Ohtsuka (2014) investigated the influence of cognitive biases on aggressive driving and found that trait driving anger and illusion of control beliefs are positively correlated with aggressive driving. Therefore, assessing for trait driving anger and illusion of control beliefs may offer another means of assessing for tendencies towards aggressive driving behaviors. Stephens and Ohtsuka conclude:

While the relationship between anger and aggressive driving is indisputable, not all angry drivers will become aggressive and not all aggressive drivers will be angry. Thus, identifying how cognitive biases may influence driving behaviour, particularly in situations where arousal is likely to influence situational evaluation is an important first step in identifying strategies to reduce these dangerous driving behaviours. (p. 128)

Identifying strategies to reduce aggressive driving behaviors and teaching these to those negatively affected by them may be an important contribution psychologists can make toward reducing traffic risk. Galovski and Blanchard (2004) report on the paucity of treatments for aggressive driving. As aggressive driving behaviors directly or indirectly cause a substantial amount of traffic accidents, developing strategies to deal with them should be high on the agenda of (traffic) psychologists. Galovski and Blanchard report on results of a controlled trail they conducted as part of the SUNY-Albany aggressive driving research program. "Treatment components included education about the ramifications of driving and anger (...), motivational techniques, progressive muscle relaxation training, discussion of alternative coping strategies (...), and cognitive strategies" (Galovski and Blanchard, 2004, pp. 122-123). The preliminary evidence is that the treatment is of significant effectiveness (p. 124). Galovski and Blanchard's article appears to be the only one in its scope and their findings, although preliminary, demand further research.

\section{Conclusion II}

\section{Suggestions regarding the role of traffic psychologists in the assessment of drivers and beyond}

Although not unique, Brazil's mandatory psychological assessment of prospective drivers is quite rare internationally. This probably means that, relatively, Brazil has significantly more active traffic psychol- 
ogists than most other countries in the world. Yet, basically what most of these traffic psychologists do is making a one-time decision about whether a prospective driver is psychologically fit to drive. Obviously this decision is based on a valid psychological assessment, but in the vast majority of cases the assessment merely offers a momentary snapshot of part of the psychological make-up of the prospective driver. In the case the prospective driver is declared psychologically fit to drive (the vast majority of cases) he or she will very likely never see a traffic psychologist again, regardless of his further psychological development or behavior in traffic, and regardless of whether he copes well with everyday driving stress or develops aggressive or otherwise risky driving behavior.

As we hope to demonstrate with this article, international data and research show at least three areas where the expertise of traffic psychologists may be called upon to make further contributions to the assessment and the advancement of the psychological fitness of existing drivers: with regards to high-risk young drivers, with regards to aggressive drivers and with regards to drivers who develop mild cognitive impairment or dementia. Particularly the subgroup of drivers exhibiting aggressive (or otherwise risky) driving behavior presents a huge opportunity for psychological intervention. Such intervention would not only decrease risk in traffic; it would likely also contribute to raising the quality of life of the affected driver and of those around him/her. Clearly many of these areas need ongoing further research. In this regard traffic psychology as an academic subject area needs to be actively promoted in Brazil. In order to be able to fulfill expanded expectations, existing and future traffic psychologists need further training, guidance and supervision, as well as a requirement of ongoing professional development.

Instead of a momentary snapshot on the basis of which a prospective driver is declared fit or unfit to drive, the initial psychological assessment of the prospective driver could become a first registration of the psychological make-up of the driver, followed up by periodical psychological "check-ins" or reviews upon license-renewal. At present, psychological assessment-data are scattered nationally over the offices of thousands of private and semi-private traffic psychologists. In the future it could be stored and consolidated centrally and made accessible to traffic researchers. This would be one way of increasing the quality and accessibility of existing data. It could become a valuable source for epidemiological research.

\section{Ethical considerations}

We are not suggesting that traffic psychologists in Brazil turn into a type of collective "Big Brother" watching over and policing the entire driver population. We much more envisage the future role of traffic psychologists to be facilitators serving to help the driving population in managing the stresses of modern motorized traffic. A driving license is literally a "license to drive", a certificate with which a society acknowledges that a person is considered able and fit to drive and with which it grants this person the right to drive on its roads. The right to drive is not a birthright and although driving is often associated with individual freedom, a license to drive is a social contract between driver and society. As worldwide experience and statistics indicate, modern traffic is associated with considerable risk (Ball, 2014). Because of their mass and speed, motor vehicles easily turn into lethal objects. Therefore, being granted the right to drive on a society's roads comes with considerable responsibility for the driver. Just like professional bodies are increasingly encouraging their members to take their responsibility for ongoing professional development seriously, engaging in modern traffic (professionally or not) comes with the responsibility for ongoing development.

Driving is much more than the sum of the skill to manage a vehicle and abiding by the rules of traffic; the modern driver has an ongoing responsibility to monitor and manage his/her actions, reactions and decisions while engaging in traffic. If a driver realizes that these actions, reactions and decisions become a risk to the driver and to others, it becomes the driver's responsibility to change them or to stop driving. This responsibility forms part of the social contract the driver engages in by carrying a driver license. However, consciously monitoring and managing one's actions, reactions and decisions as well as taking action when they are found wanting is not straightforward, as there is considerable individual and societal pressure and bias going against it. Psychological assessments ${ }^{5}$ and interventions by traffic psychologists can and should

\footnotetext{
${ }^{5}$ The right instrument, applied appropriately, can serve as a mirror in which the affected driver can observe his condition more objectively.
} 
help facilitate this responsibility. Finally, to monitor and safeguard professional accountability of traffic

\section{References}

Ball, S. (2014). Data science in transport: where do we start? TECMagazine, 55(4), 159. Retrieved from http:// www.trl.co.uk/academy-future-view/future-view/data-science-in-transport-where-do-we-start/

Bertelle, C., Duchamp G. H. E., \& Kadrri-Dahmani, H. (2009). Complex systems and self-organization modeling In A. Dumbuya, A. Booth, N. Reed, A. Kirkham, T. Philpott, J. Zhao, R. Wood, Complexity of traffic interactions: improving behavioural intelligence in driving simulation scenarios (pp. 201209). New York: Springer.

Brasil. (2001). Lei $\mathrm{n}^{\circ} 10.350$, de 21 de dezembro de 2001. Altera a Lei no 9.503, de 23 de setembro de 1997 - Código de Trânsito Brasileiro, de forma a obrigar a realização de exame psicológico periódico para os motoristas profissionais. Diário Oficial da União, $22 \operatorname{dez} 2001$.

Brasil. Ministério das Cidades. Departamento Nacional de Trânsito - Denatran. (2012). Resolução Contran No 425, de 27 de novembro de 2012. Dispõe sobre o exame de aptidão física e mental, a avaliação psicológica e o credenciamento das entidades públicas e privadas de que tratam o art. 147, I e $\$ \S$ $1^{\circ} \mathrm{a} 4^{\circ} \mathrm{e}$ o art. 148 do Código de Trânsito Brasileiro. Diário Oficial da União, 10 dez. 2012.

Cobb, R. W., \& Coughlin, J. F. (1998). Are elderly drivers a road hazard? Problem definition and political impact. Journal of Aging Studies, 12(4), 411-427. doi:10.1016/S0890-4065(98)90027-5

Departamento Nacional de Infraestrutura de Transportes - DNIT. (2015). Estatísticas de acidentes. Brasília, DF: the author. Retrieved from http://www. dnit.gov.br/rodovias/operacoes-rodoviarias/estatisticas-de-acidentes

European Road Safety Observatory (2007). Characteristics of these crashes. Retrieved from http:// ec.europa.eu/transport/wcm/road_safety/erso/ knowledge/Content/06_young/characteristics_of_ these_crashes.htm

Fisher, M., \& Thomson S. (2014). Dementia and driving safety: a clinical guideline: version 3.Auckland: Driving with Dementia Working Group. Retrieved from http:// psychologists, professional supervision should become an integral part of the job (O`Neill, 2004).

www.alzheimers.org.nz/getmedia/59fcfc70-8f96-43da-bf7a-1f640dceadd0/Dementia_and_Driving.pdf/

Galovski, T. E., \& Blanchard, E. B. (2004). Road rage: a domain for psychological intervention? $A g$ gression and Violent Behavior, 9(2), 105-127. doi:10.1016/S1359-1789(02)00118-0

Insurance Institute for Highway Safety, Highway Loss Data Institute (2015). Teenagers: 2013: fatality facts. Ruckserville: the author. Retrieved from http://www.iihs. org/iihs/topics/t/teenagers/fatalityfacts/teenagers

Johnson, S. B., Blum, R. W., \& Giedd, J. N. (2009). Adolescent maturity and the brain: the promise and pitfalls of neuroscience research in adolescent health policy. Journal of Adolescent Health, 45, 216-221. doi:10.1016/j.jadohealth.2009.05.016

Langford, J., Methorst, R., \& Hakamies-Blomqvist, L. (2006). Older driver do not have a high crash risk: a replication of low mileage bias. Accident Analysis and Prevention, 38(3), 574-578. doi:10.1016/j.aap.2005.12.002

McKnight, A. J., \& Peck, R. C. (2003). Graduated driver licensingand saferdriving.JournalofSafetyResearch, 34(1), 85-89. doi:10.1016/S0022-4375(02)00084-1

Mori, Y., \& Mizohata, M. (1994). Characteristics of older road users and their effect on road safety. Accident Analysis and Prevention, 27(3), 391-404. doi:10.1016/0001-4575(94)00077-Y

Morris, J. (1993). The Clinical Dementia Rating (CDR): Current vision and scoring rules. Neurology, 43(11), 2412-2414.

New Zealand. Ministry of Transport. (2012). High risk drivers in fatal and serious crashes 2006-2010. Retrieved from http://www.transport.govt.nz/research/roadcrashstatistics/highriskdriversstatistics/

NationalHighwayTrafficSafetyAdministration-NHTSA. (2008). National Center for Statistics and Analysis (2008). Traffic safety facts: 2008 data: older population. Washington , DC: the author.

O'Neill, E. (2004). Professional supervision: myths, culture and structure. Tipperary: RMA Publications.

Por Vias Seguras. (2015). Indices de acidentes de trânsito. Retrieved from http://www.vias-seguras.com/os_acidentes/estatisticas/indices_de_acidentes_de_transito 
Por Vias Seguras. (2007). Taxas de vítimas fatais. Retrieved from http://www.vias-seguras.com/index. php/os_acidentes/estatisticas/indices_de_acidentes_de_transito/taxas_de_vitimas_fatais

RAC Foundation. (2016). Road Safety FAQs. London: the author. Retrieved from http://www.racfoundation.org/motoring-faqs/safety

Ross, H. L. (1940). Traffic accidents: a product of social-psychological conditions. Social Forces, 18, 569-576.

Steinberg, L. (2008). A social neuroscience perspective on adolescent risk-taking. Developmental Review, 28(1), 78-106. doi:10.1016/j.dr.2007.08.002

Stephens, A.N. ,\& Ohtsuka, K. (2014). Cognitive biases in aggressive drivers: does illusion of control drive us of the road? Personal and Individual Differences, 68, 124-129. doi:10.1016/j.paid.2014.04.016

Stradling, S. G., \& Parker, D. (1997). Extending the theory of planned behaviour: the role of personal norm, instrumental beliefs, and affective beliefs in predicting driving violations (pp. 367-374). In J. A. Rothengatter, \& E. Carbonell (Eds.), Traffic and transport psychology: theory and application. Amsterdam: Emerald.

Tonkin, R.S. (1987). Adolescent risk-taking behavior. Journal of Adolescent Health Care, 8(2), 213-220. doi:10.1016/0197-0070(87)90269-5

Williams, A.F. (2002). Teenage drivers: patterns of risks. Journal of Safety Research, 34(1), 5-15. doi:10.1016/S0022-4375(02)00075-0

World Health Organization. (2015). Global status report on road safety 2015. Geneva: World Health Organization.

\author{
Paulus AJ M de Wit \\ Graduação em Psicologia pela Open University, \\ Inglaterra. \\ E-mail: pdwpsi@gmail.com
}

Caroline Zaneripe de Souza

Acadêmica de Psicologia pela Universidade Federal de Santa Catarina, Florianópolis - SC. Brasil.

E-mail: carolzpsi@gmail.com

\section{Roberto Moraes Cruz}

Doutor. Docente da Universidade Federal de Santa Catarina, Florianópolis - SC. Brasil.

E-mail: robertocruzdr@gmail.com

Endereço para envio de correspondência: Laboratório Fator Humano. Universidade Federal de Santa Catarina. Centro de Filosofia e Ciências Humanas, Sala 13A. Campus Universitário Trindade. CEP: 88040-970.

Florianópolis - SC. Brasil.

Recebido 01/07/2016

Aprovado 24/08/2016

Received 07/01/2016

Approved 08/24/2016

Recibido 01/07/2016

Aceptado 24/08/2016

How to cite:Wit, P. A. J. M.; Souza, C. Z.; Cruz, R. M. (2016). Improving accident statistics and expanding the role of traffic psychologists in Brazil. Psicologia: Ciência e Profissão, 36(4): 816-830. DOI: 10.1590/1982-3703002382016

Cómo citar:Wit, P. A. J. M.; Souza, C. Z.; Cruz, R. M. (2016). Melhorando as estatísticas de acidentes e ampliando o papel dos psicólogos do trânsito no Brasil. Psicologia: Ciência e Profissão, 36(4): 816-830.

DOI: $10.1590 / 1982-3703002382016$

Como citar:Wit, P. A. J. M.; Souza, C. Z.; Cruz, R. M. (2016). Mejorando las estadísticas de accidentalidad y ampliando el papel de los psicólogos del tráfico en Brasil. Psicologia: Ciência e Profissão, 36(4): 816-830. DOI: $10.1590 / 1982-3703002382016$ 